\title{
Effect of Multienzymes and Absorption Enhancers on Productive Performance, Gut Morphology and Some Blood Biochemical and Hormonal Parameters in Broiler Chicks
}

\author{
Hodallah H. Ahmed ${ }^{1}$, N.S. El-Toukhey ${ }^{1}$, K.A. Attia ${ }^{1} \&$ Salma I. El-Samannoudy $^{1}$ \\ ${ }^{1}$ Department of Physiology, Faculty of Vet. Med., Cairo University, Giza, Egypt \\ Correspondence: Hodallah H. Ahmed, Department of Physiology, Faculty of Vet. Med., Cairo University, \\ Giza-12211, Egypt. Tel: 20-0100-5625-432. E-mail: hodaahatem@yahoo.com
}

Received: July 15, 2013 Accepted: September 23, 2013 Online Published: November 15, 2013

doi:10.5539/jas.v5n12p162 URL: http://dx.doi.org/10.5539/jas.v5n12p162

\begin{abstract}
The present study was carried out to investigate the effect of polyzyme and lysoforte either alone or in combination on productive performance and some metabolic parameters in broiler chicks. Two hundred and forty, one day old, Cobb chicks were divided into four groups, the first group was fed on a basal ration without any additives and kept as a control, the second group was fed on a basal ration supplemented with polyzyme at a dose of $400 \mathrm{gm} /$ ton ration, the third group was fed on a basal ration to which lysoforte was added at a dose of $250 \mathrm{gm} / \mathrm{ton}$ ration and the fourth group was fed on a basal diet to which polyzyme $400 \mathrm{~g} / \mathrm{ton}$ and lysoforte 250 $\mathrm{g} /$ ton were added. Both feed additives either alone or in combination produced a significant improvement in body weight, body weight gain and feed conversion ratio during most of the first seven weeks. All supplemented groups showed no significant changes in the activities of ALP, AST, ALT and levels of creatinine and cholesterol versus control during the whole sampling periods. Polyzyme induced a significant increase in serum triglycerides level at the $4^{\text {th }}$ week of the experiment, while at the $6^{\text {th }}$ and $8^{\text {th }}$ week both polyzyme and lysoforte produced a significant increase in its level versus control. Blood glucose level was significantly increased in lysoforte supplemented groups at the $6^{\text {th }}$ weeks and in polyzyme and lysoforte supplemented groups at the $8^{\text {th }}$ weeks. No significant changes in TSH and T4 levels were recorded during the whole sampling periods. At the $8^{\text {th }}$ week the control group exhibited the lowest level of T3. The length of villi and depth of crypts of small intestine of supplemented groups were significantly higher than those of the control groups. All feed additives did not produce any obvious histopathological changes in the examined organs.
\end{abstract}

Keywords: broilers, blood parameters, enzymes, growth, lysoforte

\section{Introduction}

Growth promoters can be defined as substances which will increase growth rate and/or increase feed efficiency in healthy farm animals fed a balanced diet (Armstrong, 1986). They are chemical and biological substances which are added to livestock feed with the aim to improve the growth of chicken, improve the utilization of food and in this way realize better production and financial results (Peric et al., 2009). Several antibiotics have been used as growth promoters in farm animals. Antibiotics were found to improve feed conversion and animal growth as well as to reduce morbidity and mortality in clinical and subclinical diseases (Ewing \& Cole, 1994). However, in 2006 Europe banned using antibiotics as growth promoters in animal nutrition due to the development of microbial resistance and the potential harmful effects on human health. Toghyani et al. (2010) stated that the use of some antibiotics as growth promoters creates a huge problem for environmental condition and health of consumers around the world. As it results in transmission and proliferation of resistant bacteria via food chain, development of resistance in human and animal pathogen and presence of antibiotic residues in animal products (Houshmand et al., 2011). Consequently, Peric et al. (2009) reported that withdrawal of antibiotics from poultry foods created need for alternative solutions (i.e., other natural substances) which would influence improvement of health and production traits of broiler chickens. The authors added that nowadays, several groups of these additives are in use such as probiotics, prebiotics, enzymes, acidifiers, antioxidants and absorption enhancers. Enzymes, even in small quantities can initiate or accelerate the rate of chemical reactions that transform dietary substrates into products of biological significance for broiler growth and production (Taylor-pickard \& Spring, 2008). Moreover, enzymes were found to be effective in improving growth 
performance especially at early age because at this age the birds might be limited in their capacity to produce the digestive enzymes (Olukosi et al., 2007). Mathlouthi et al. (2002) concluded that exogenous enzymes improved nutrient digestibility and broiler chicken performance by improving the absorption capacity of small intestine through increasing villus surface and intestinal concentration of conjugated bile acid. Pettersson and Aman (1989) attributed the growth promoting effect of enzymes to:1) its ability to increase the access to nutrients previously bound in or by cell walls; 2) its ability to combine with endogenous enzymes and help in degrading compounds to a size that can be utilized by the animal (consequently it was found to be important to choose exogenous enzymes with complementary action to enzymes produced by the animal) and 3) prevent the increase in digesta viscosity, which can impair nutrient absorption (some compounds once they are released from the cell walls, form gels which can increase digesta viscosity). However, there are some contrasting opinions on the effect of enzyme supplementation on chicks performance. Douglas et al. (2000) recorded that broilers performance was not affected by enzymes supplementation, while, Hajati et al. (2009) found that adding enzymes to broilers diet significantly decreased body weight gain, feed intake and improved feed gain ratio, energy and protein efficiency.

The use of supplemental fats and oils in broiler chicken diets as an energy source has become a wide-spread practice in the feed industry (Hertrampf, 2001). The problem of fat digestion is that this process takes place in an aqueous environment as gastrointestinal tract, although fats are not water soluble. Fats are emulsified by the detergent action of the bile salt and hydrolyzed by lipase into fatty acids and mono and di-glycerides. Transport of fat and mono and di-glyceride occurs in the form of micelles. Therefore, biosurfactant are needed such as phospholipids, lysolecithin (lysoforte) and lecithin (Soares \& Lopez-Bote, 2002). The authors further added that Lysoforte is a specific natural biosurfactant highly enriched in phospholipids which proved to have the ability as an absorptive enhancer in poultry and animals. Nakano et al. (2009) confirmed the importance of lysoforte in the lipid absorption process and showed that lysoforte facilitates the efficient intestinal lipid transport by accelerating lipid absorption, lipoprotein assembly and lipid clearance. Melegy et al. (2010) carried out a number of trials to evaluate the efficiency of lysoforte in enhancing animal digestion as well as performance. They concluded that lysoforte is a natural bio-surfactant that can significantly improve broiler performance by enhancing feed utilization and nutrient absorption.

The aim of the current study was to evaluate the effect of supplementation of broiler feed with polyzyme and lysoforte either alone or in combination on productive performance, gut morphology, histopathological changes and some blood biochemical and hormonal parameters of broiler chicks.

\section{Material and Methods}

\subsection{Birds}

Two hundred and forty, one day old Cobb chicks were used. Chicks were kept on lighting regimen of 23 hrs light daily (Mousa, 2008) and temperature were kept at $31^{\circ} \mathrm{C}$ using air warmers during the first 2 weeks then decreased gradually till $29^{\circ} \mathrm{C}$ according to recommendations obtained from the providing company. Chicks were fed on starter ration during the first four weeks, grower ration during the next two weeks and finisher ration during the final two weeks (Table 1). At 3 weeks of age, it could be able to distinguish between male and female chicks. Females were excluded and the experiment was continued on males only. 
Table 1. Composition of percentage and calculated nutrients profile of the basal diets.

\begin{tabular}{llll}
\hline Ingredients \% & $\begin{array}{l}\text { Starter } \\
(1-30 \text { day })\end{array}$ & $\begin{array}{l}\text { Grower } \\
(30-45 \text { day })\end{array}$ & $\begin{array}{l}\text { Finisher } \\
(45-60 \text { day })\end{array}$ \\
\hline Yellow corn & 51.70 & 56.15 & 61.15 \\
Corn gluten meal & 5.00 & 5.00 & 5.00 \\
Soybean meal (44\% CP) & 37.30 & 31.50 & 25.90 \\
Soy oil & 2.20 & 3.50 & 4.00 \\
Dicalcium phosphate & 1.60 & 1.60 & 1.70 \\
Limestone & 1.40 & 1.45 & 1.44 \\
Common salt & 0.40 & 0.40 & 0.40 \\
DL-Methionine & 0.05 & 0.05 & 0.06 \\
L-Lysin & 0.05 & 0.05 & 0.05 \\
Vitamin\&mineral premix* & 0.30 & 0.30 & 0.30 \\
Calculated analysis: & 2951.80 & 3049.55 & 3124.07 \\
ME (Kcal/kg) & 23.20 & 21.29 & 19.00 \\
Crude protein\% & 6.00 & 6.92 & 8.00 \\
Crude fat\% & 4.50 & 4.80 & 5.20 \\
Crude fiber\% & 1.00 & 1.00 & 1.00 \\
Calcium\% & 0.45 & 0.45 & 0.45 \\
Non-phytate phosphorus\%
\end{tabular}

*Per kg premix: $1200000 \mathrm{IU}$-vit. A, $350000 \mathrm{IU}$ - vit. $\mathrm{D}_{3}, 4000 \mathrm{mg}$ - vit. E, $250 \mathrm{mg}$ - vit. $\mathrm{B}_{1}, 800 \mathrm{mg}$ - vit. $\mathrm{B}_{2}$, $600 \mathrm{mg}$ - vit. $\mathrm{B}_{6}, 3.2 \mathrm{mg}$-vit. $\mathrm{B}_{12}, 450 \mathrm{mg}$ - vit. $\mathrm{K}_{3}, 4.5 \mathrm{~g}$ nicotinic acid, $1.5 \mathrm{~g}$ Ca-pantothenate, $120 \mathrm{mg}$ folic acid, $5 \mathrm{mg}$ biotin, $55 \mathrm{~g}$ choline chloride, $3 \mathrm{~g} \mathrm{Fe}, 2 \mathrm{~g} \mathrm{Cu}, 10 \mathrm{~g} \mathrm{Mn}, 8 \mathrm{~g} \mathrm{Zn}, 120 \mathrm{mg}$ I, $40 \mathrm{mg}$ Co.

\subsection{Feed Additives}

\subsubsection{Polyzyme}

A multi-enzyme feed additive, containing xylanase, cellulose, B-glucanase, pectinase, amylase, protease, lipase, phytase, galactosidase, mannanase. It was a gift from Dr. Hamed El-Banna, Delta Vet Center, Heliopolis, Cairo.

\subsubsection{Lysoforte}

A natural biosurfactant highly enriched in Lyso-Phosphophatidylcholine (LPC), manufactured by Kemin Europa.

\subsection{Experimental Design}

Chicks were randomly divided into 4 equal groups of 60 birds each. They were treated as follows: The first group was kept as a control group and fed on a basal ration without any additives. The second group was fed on a basal ration to which polyzyme powder was added at a dose equal to $400 \mathrm{~g} /$ ton as recommended by Delta Vet Company. The third group was fed on a basal ration to which lysoforte powder was added at a dose equal to 250 $\mathrm{g} /$ ton ration as recommended by the providing company. The fourth group was fed on a basal ration to which lysoforte powder ( $250 \mathrm{~g} /$ ton ration) and polyzyme powder ( $400 \mathrm{~g} /$ ton ration) were added.

\subsection{Sampling}

\subsubsection{Blood Samples}

Blood samples were collected from 10 chicks in each group at the end of the $4^{\text {th }}, 6^{\text {th }}$ and $8^{\text {th }}$ weeks of the experiment by slaughtering. Sera were obtained and stored at $-20^{\circ} \mathrm{C}$ till assays were carried out. Except for glucose which was measured immediately after sample collection. 


\subsubsection{Tissue Samples}

At the end of the experiment 5 birds from each group were slaughtered a) Tissue samples from liver, spleen and bursa of Fabricious were obtained for histopathological examination and b) Tissue samples from duodenum, jujenum and ileum were taken for studying the morphology of GIT

\subsection{Measured Parameters}

\subsubsection{Growth Parameter}

The initial body weights of all birds on the $1^{\text {st }}$ day of age were measured. The weekly changes in the live body weight and the daily feed consumption were calculated to compute the following: Average daily feed intake (g/day), average weekly body weight gain ( $\mathrm{g} /$ week), feed efficiency and feed conversion ratio.

\subsubsection{Biochemical Parameter}

Alkaline phosphatase activity (ALP) was estimated by the kinetic UV method of Wenger et al. (1984). Aspartate aminotransferase (AST), Alanine aminotransferase (ALT) and Creatinine were estimated by the colorimetric-kinetic methods of Murray et al. (1984). Cholesterol was estimated by the colorimetric method of Meiattini et al. (1978). Triglycerides were estimated by the colorimetric method of Fossati and Prencipe (1982). Glucose was estimated by the colorimetric method of Burtis and Ashwood (1999). All parameters were measured in the serum using kits obtained from Spinreact Diagnostic Company and purchased from New Star Company in Kasr El-Ainy Street.

\subsubsection{Determination of Some Metabolic Hormones}

Thyroid stimulating hormone, thyroxine and tri-iodothyronine was estimated by the colorimetric method of Thakur et al. (1997). Hormone kits were obtained from Calbiotech Diagnostic Company and purchased from Newstar Company.

\subsubsection{Histopathological Examination}

At the end of the experiment 5 birds from each group were slaughtered and Autopsy samples were taken from the liver, spleen and bursa of Fabricus, fixed in $10 \%$ formol saline for twenty four hours. Washing was done in tap water then serial dilutions of alcohol (methyl, ethyl and absolute ethyl) were used for dehydration. Specimens were cleared in xylene and embedded in paraffin at $56{ }^{\circ} \mathrm{C}$ in hot air oven for twenty four hours. Paraffin bees wax tissue blocks were prepared for sectioning at 4 microns slidge microtome.The obtained tissue section were collected on glass slides, deparaffinised and stained by hematoxylin and eosin stains for histopathological examination through the electric light microscope (Banchroft et al., 1996).

2.5.5 Measurement of the Length of the Intestinal Villi and the Depth of Crypts of Liherkuhn

Tissue samples were taken from duodenum, jejunum and ileum. They were treated as mentioned before in histopathological examination, stained with heamatoxilin and eosin (H\&E) stain for measuring the length of the intestinal villi and the depth of crypts using light microscope. A computerized microscopic image analyzer attached for full HD microscopic camera (Leica Microsystems, Germany) was used to determine the histomorphometric parameters.

\subsection{Statistical Analysis}

All Data were presented as Mean \pm Standard error. They were subjected to one way analysis of variance test according to Snedecor and Cochran (1980) using statistical analysis system program (Instat-3).

\section{Results}

\subsection{Effect on Growth Performance}

\subsubsection{Average Weekly Body Weight}

There was a significant increase in the average body weight of all supplemented groups versus control during most of the experimental periods (Table 2). 
Table 2. Effect of polyzyme and/or lysoforte on the average weekly live body weight (g) in broiler chicks

\begin{tabular}{ccccc}
\hline \multirow{2}{*}{ Period (week) } & \multicolumn{4}{c}{ Body weight $(\mathrm{g})$} \\
\cline { 2 - 5 } & Control & Polyzyme & Lysoforte & Poly.+ Lyso. \\
\hline 0 & $52.983 \pm 0.52$ & $53.63 \pm 0.53$ & $52.87 \pm 0.44$ & $54.08 \pm 0.54$ \\
1 & $172.58 \pm 2.86^{\mathrm{ab}}$ & $191.28 \pm 2.83^{\mathrm{a}^{* * *}}$ & $182.78 \pm 2.59^{\mathrm{c}}$ & $194.35 \pm 2.95^{\mathrm{bc} * *}$ \\
2 & $379.75 \pm 5.63^{\mathrm{abc}}$ & $412.96 \pm 6.56^{\mathrm{a}^{*}}$ & $416.51 \pm 5.37^{\mathrm{b}^{*}}$ & $416.65 \pm 6.22^{\mathrm{c}^{* *}}$ \\
3 & $706.04 \pm 9.82^{\mathrm{abc}}$ & $751.98 \pm 8.37^{\mathrm{a}^{*}}$ & $753.98 \pm 7.39^{\mathrm{b}^{*}}$ & $752.81 \pm 9.15^{\mathrm{c}^{*}}$ \\
4 & $955.59 \pm 15.57^{\mathrm{abc}}$ & $1126.9 \pm 14.52^{\mathrm{a}^{* * *}}$ & $1113.1 \pm 17.35^{\mathrm{b}^{* * *}}$ & $1133.3 \pm 12.37^{\mathrm{c} * *}$ \\
5 & $1566.3 \pm 23.88^{\mathrm{abc}}$ & $1658.8 \pm 22.34^{\mathrm{a}^{*}}$ & $1670.5 \pm 28.00^{\mathrm{b}^{\mathrm{b}}}$ & $1681.7 \pm 26.51^{\mathrm{c}^{*}}$ \\
6 & $1940.5 \pm 30.15^{\mathrm{ab}}$ & $2108.6 \pm 32.27$ & $2190.5 \pm 40.40^{\mathrm{a}^{* *}}$ & $2168.1 \pm 41.02^{\mathrm{b}^{* * *}}$ \\
7 & $2307.3 \pm 41.21^{\mathrm{ab}}$ & $2493.2 \pm 64.41$ & $2560.7 \pm 59.00^{\mathrm{a}^{*}}$ & $2525 \pm 65.14 .31^{\mathrm{b}^{*}}$ \\
8 & $2800.5 \pm 61.84^{\mathrm{a}}$ & $3068.8 \pm 67.62$ & $3178.9 \pm 101.05^{\mathrm{a}^{*}}$ & $2990.7 \pm 73.32$ \\
\hline
\end{tabular}

Each value expressed as Mean \pm Standard Error.

Means having the same letter in the same row are significantly different.

${ }^{+} 0=$ mean value of pre supplementation weight.

${ }^{*} \mathrm{p}<0.05,{ }^{* *} \mathrm{p}<0.01,{ }^{* * *} \mathrm{p}<0.001$ versus control.

\subsubsection{Average Weekly Live Body Weight Gain}

The data represented in Table 3 shows the effect of feed supplementation with polyzyme and/or lysoforte on the average weekly live body weight gain. The results indicated that supplementation of feed with polyzyme and lysoforte either alone or in combination significantly increased the average body weight gain of all supplemented groups during the first 6 weeks of the experiment, except for the 2nd week where the increase was only significant in group supplemented with lysoforte. However, No significant differences were observed between all supplemented groups during most of the experimental period.

Table 3. Effect of polyzyme and/or lysoforte on the average weekly live body weight gain (g) in broiler chicks

\begin{tabular}{ccccc}
\hline \multirow{2}{*}{ Period (week) } & \multicolumn{4}{c}{ Body weight gain $(\mathrm{g})$} \\
\cline { 2 - 5 } & Control & Polyzyme & Lysoforte & Poly.+ Lyso. \\
\hline 1 & $119.39 \pm 2.35^{\mathrm{abc}}$ & $137.65 \pm 2.30^{\mathrm{a}^{* * *}}$ & $129.92 \pm 2.52^{\mathrm{b}^{* *}}$ & $140.27 \pm 2.07^{\mathrm{c} * *}$ \\
2 & $217.45 \pm 2.94^{\mathrm{a}}$ & $223.53 \pm 3.91^{\mathrm{b}}$ & $239.16 \pm 3.50^{\mathrm{ab}^{\mathrm{b} * *}}$ & $226.45 \pm 2.82$ \\
3 & $318.53 \pm 4.20^{\mathrm{abc}}$ & $340.64 \pm 2.46^{\mathrm{a}^{* * *}}$ & $333.57 \pm 3.86^{\mathrm{b}^{* *}}$ & $338.50 \pm 2.75^{\mathrm{c}^{* * *}}$ \\
4 & $243.91 \pm 6.52^{\mathrm{abc}}$ & $382.69 \pm 7.73^{\text {ad }} \mathrm{d}^{* * *}$ & $351.48 \pm 6.20^{\mathrm{bd} * * *}$ & $367.48 \pm 5.29^{\mathrm{c}^{* * *}}$ \\
5 & $461.7 \pm 13.02^{\mathrm{abc}}$ & $569.88 \pm 14.20^{\mathrm{a}^{* * *}}$ & $616.16 \pm 17.43^{\mathrm{b}^{\mathrm{b**}}}$ & $592.03 \pm 17.90^{\mathrm{c}^{* *}}$ \\
6 & $378.75 \pm 4.33^{\mathrm{abc}}$ & $540.86 \pm 11.53^{\mathrm{a}^{* * *}}$ & $524.16 \pm 18.90^{\mathrm{b}^{* * *}}$ & $542.47 \pm 14.99^{\mathrm{c}^{* * *}}$ \\
7 & $489.06 \pm 30.42^{\mathrm{a}}$ & $644.09 \pm 41.48^{\mathrm{a} *}$ & $567.5 \pm 31.44$ & $584.29 \pm 43.63$ \\
8 & $497.92 \pm 12.94$ & $585.29 \pm 29.01$ & $578.57 \pm 22.78$ & $541.08 \pm 42.76$ \\
\hline
\end{tabular}

Each value is expressed as Mean \pm Standard Error.

Means having the same letter in the same row are significantly different.

$* * \mathrm{p}<0.01, * * * \mathrm{p}<0.001$ versus control.

\subsubsection{Average Weekly Feed Intake}

Table 4 clarifies the effect of feed supplementation with polyzyme and lysoforte either alone or in combination on the average weekly feed intake. No significant differences were observed in the average weekly feed intake in all experimental groups during most of the experimental periods. 
Table 4. Effect of polyzyme and/or lysoforte on the average weekly feed intake in broiler chicks

\begin{tabular}{ccccc}
\hline \multirow{2}{*}{ Period (week) } & \multicolumn{4}{c}{ Feed intake $(\mathrm{g})$} \\
\cline { 2 - 5 } & Control & Polyzyme & Lysoforte & Poly.+ Lyso. \\
\hline 1 & $34.7 \pm 0.33^{\mathrm{a}}$ & $35.02 \pm 0.53$ & $34.26 \pm 0.24^{\mathrm{b}}$ & $36.90 \pm 0.75^{\mathrm{ab}^{*}}$ \\
2 & $50.20 \pm 3.78$ & $55.48 \pm 3.47$ & $59.50 \pm 4.36$ & $63.76 \pm 4.61$ \\
3 & $80.65 \pm 1.44^{\mathrm{a}}$ & $88.93 \pm 2.58$ & $92.79 \pm 3.35^{\mathrm{a}^{*}}$ & $90.65 \pm 2.94$ \\
4 & $117.32 \pm 2.96$ & $108.64 \pm 1.48$ & $113.25 \pm 5.25$ & $110.42 \pm 2.05$ \\
5 & $141.92 \pm 3.81$ & $134.91 \pm 4.49$ & $142.41 \pm 4.71$ & $143.35 \pm 1.91$ \\
6 & $121.95 \pm 6.10$ & $117.05 \pm 5.11$ & $134.65 \pm 5.58$ & $128.31 \pm 6.03$ \\
7 & $211 \pm 2.84$ & $198.25 \pm 11.44$ & $202.36 \pm 4.20$ & $197.43 \pm 5.73$ \\
8 & $192.99 \pm 3.52$ & $182.01 \pm 7.1$ & $205.15 \pm 7.87$ & $191.58 \pm 8.66$ \\
\hline
\end{tabular}

Each value is expressed as Mean \pm Standard Error.

Means having the same letter in the same row are significantly different.

$* \mathrm{p}<0.05$ versus control.

\subsubsection{Feed Conversion Ratio}

It is shown from table (5) that there was a significant decrease in the feed conversion ratio of all supplemented groups versus control starting from the end of the 4th week and extended to the end of the 7th week of the experimental period. No significant differences in feed conversion ratio of all supplemented groups versus control group were seen at the end of the 8th week. No significant differences were observed between all supplemented groups during most of the experimental period.

Table 5. Effect of polyzyme and/or lysoforte on feed conversion ratio in broiler chicks

\begin{tabular}{ccccc}
\hline \multirow{2}{*}{ Period (Week) } & \multicolumn{4}{c}{ Feed conversion ratio } \\
\cline { 2 - 5 } & Control & Polyzyme & Lysoforte & Poly.+ Lyso. \\
\hline 1 & $1.91 \pm 0.02$ & $1.81 \pm 0.03$ & $1.80 \pm 0.03$ & $1.87 \pm 0.03$ \\
2 & $1.69 \pm 0.03^{\mathrm{a}^{* * *}}$ & $1.72 \pm 0.03^{\mathrm{b}}$ & $1.76 \pm 0.03^{\mathrm{c}}$ & $1.98 \pm 0.02^{\mathrm{abc}}$ \\
3 & $1.79 \pm 0.03^{\mathrm{ab}}$ & $1.83 \pm 0.01$ & $1.95 \pm 0.02^{\mathrm{a}^{* * *}}$ & $1.86 \pm 0.01^{\mathrm{b}^{*}}$ \\
4 & $3.53 \pm 0.10^{\mathrm{abc}}$ & $2.0 \pm 0.03^{\mathrm{a}^{* * *}}$ & $2.29 \pm 0.04^{\mathrm{b}^{* * *}}$ & $2.04 \pm 0.03^{\mathrm{c} * *}$ \\
5 & $2.21 \pm 0.08^{\mathrm{abc}}$ & $1.75 \pm 0.03^{\mathrm{a}^{* * *}}$ & $1.85 \pm 0.05^{\mathrm{b}^{* * *}}$ & $1.95 \pm 0.06^{\mathrm{c}^{* *}}$ \\
6 & $2.27 \pm 0.03^{\mathrm{abc}}$ & $1.63 \pm 0.05^{\mathrm{a}^{* * *}}$ & $1.88 \pm 0.04^{\mathrm{b}^{* * *}}$ & $1.71 \pm 0.04^{\mathrm{c} * *}$ \\
7 & $3.92 \pm 0.14^{\mathrm{abc}}$ & $2.81 \pm 0.19^{\mathrm{a}^{* * *}}$ & $2.64 \pm 0.10^{\mathrm{b}^{* * *}}$ & $2.21 \pm 0.10^{\mathrm{c} * *}$ \\
8 & $2.73 \pm 0.09$ & $2.28 \pm 0.10$ & $2.54 \pm 0.12$ & $2.83 \pm 0.20$ \\
\hline
\end{tabular}

${ }^{*} \mathrm{p}<0.05, * * \mathrm{p}<0.01, * * * \mathrm{p}<0.001$ versus control.

\subsection{Effect on Some Blood Biochemical Parameters}

3.2.1 Alkaline Phosphatase (ALP), Aspartate Aminotransferase (AST) and Alanine Aminotransferase (ALT)

Tables (6-8) show that there were no significant differences between control and all supplemented groups in the activities of ALP, AST and ALT, respectively in the serum of broiler chicks during all sampling periods. 
Table 6. Effect of polyzyme and/or lysoforteo on alkaline phosphatase (ALP) activity in serum of broiler chicks

\begin{tabular}{ccccc}
\hline \multirow{2}{*}{ Period (weeks) } & \multicolumn{4}{c}{ ALP (U/L) } \\
\cline { 2 - 5 } & Control & Polyzyme & Lysoforte & Poly.+Lyso. \\
\hline 4 & $526 \pm 65.66$ & $363.75 \pm 78.20$ & $427.55 \pm 96.23$ & $343.38 \pm 92.11$ \\
6 & $562.58 \pm 42.19$ & $507.05 \pm 61.93$ & $613.45 \pm 35.01$ & $548.80 \pm 55.73$ \\
8 & $630.30 \pm 79.28$ & $549.12 \pm 35.40$ & $509.52 \pm 57.00$ & $665.50 \pm 27.69$
\end{tabular}

Each value is expressed as Mean \pm Standard Error.

Table 7. Effect of polyzyme and/or lysoforte on aspartate aminotransferase (AST) activity in serum of broiler chicks

\begin{tabular}{ccccc}
\hline Period (weeks) & Control & Polyzyme & Lysoforte & Poly.+ Lyso. \\
\hline 4 & $30.98 \pm 3.35$ & $31.26 \pm 5.16$ & $35.02 \pm 2.32$ & $27.56 \pm 4.02$ \\
6 & $28.98 \pm 4.50$ & $30.40 \pm 3.54$ & $19.66 \pm 4.52$ & $30.49 \pm 5.07$ \\
8 & $29.57 \pm 3.83$ & $32.973 \pm 3.88$ & $29.97 \pm 4.88$ & $27.21 \pm 3.64$ \\
\hline
\end{tabular}

Each value is expressed as Mean \pm Standard Error.

Table 8. Effect of polyzyme and/or lysoforte on alanine aminotransferase (ALT) activity in serum of broiler chicks

\begin{tabular}{ccccc}
\hline \multirow{2}{*}{ Period (weeks) } & \multicolumn{4}{c}{ GPT (RFU/ml) } \\
\cline { 2 - 5 } & Control & Polyzyme & Lysoforte & Poly.+ Lyso. \\
\hline 4 & $15.325 \pm 0.35$ & $20.623 \pm 2.39$ & $16.677 \pm 1.72$ & $16.230 \pm 1.77$ \\
6 & $16.317 \pm 1.97$ & $20.116 \pm 3.09$ & $31.163 \pm 5.78$ & $27.587 \pm 3.89$ \\
8 & $24.477 \pm 2.25$ & $28.122 \pm 3.68$ & $28.113 \pm 4.71$ & $37.435 \pm 3.46$ \\
\hline
\end{tabular}

Each value is expressed as Mean \pm Standard Error.

\subsubsection{Creatinine}

Table 9 shows the effect of lysoforte and/or polyzyme on creatinine level in serum of broiler chicks. No significant alterations in serum creatinine levels were recorded between all experimental groups at 4,6 and 8 weeks of the experiment.

Table 9. Effect of polyzyme and/or lysoforte on serum creatinine in broiler chicks

\begin{tabular}{ccccc}
\hline \multirow{2}{*}{ Period (weeks) } & \multicolumn{4}{c}{ Creatinine (mg/dl) } \\
\cline { 2 - 5 } & Control & Polyzyme & Lysoforte & Poly. + Lyso. \\
\hline 4 & $2.89 \pm 0.42$ & $3.25 \pm 0.39$ & $2.44 \pm 0.48$ & $2.89 \pm 0.31$ \\
6 & $1.22 \pm 0.27$ & $2 \pm 0.38$ & $1.43 \pm 0.31$ & $1.1 \pm 0.22$ \\
8 & $0.36 \pm 0.10$ & $0.4 \pm 0.06$ & $0.46 \pm 0.06$ & $0.6 \pm 0.09$ \\
\hline
\end{tabular}

Each value is expressed as Mean \pm Standard Error.

\subsubsection{Cholesterol}

It is shown from Table 10 that there were no significant differences in serum cholesterol level between control and all supplemented groups during the whole sampling periods. However, at the 6th week of the experiment serum cholesterol level in the group supplemented with polyzyme was significantly lower than those supplemented with lysoforte either alone or in combination with polyzyme. 
Table 10. Effect of polyzyme and/or lysoforte on cholesterol level in serum of broiler chicks

\begin{tabular}{ccccc}
\hline \multirow{2}{*}{ Period (weeks) } & \multicolumn{4}{c}{ Cholesterol(mg/dl) } \\
\cline { 2 - 5 } & Control & Polyzyme & Lysoforte & Poly. +Lyso. \\
\hline 4 & $163.54 \pm 20.93$ & $179.17 \pm 13.19$ & $184.81 \pm 20.76$ & $186.67 \pm 13.61$ \\
6 & $135.37 \pm 9.73$ & $99.028 \pm 12.49^{\text {ab }}$ & $170.73 \pm 12.87^{\mathrm{a}}$ & $172.04 \pm 15.69^{\mathrm{b}}$ \\
8 & $113.7 \pm 11.75$ & $133.01 \pm 16.14$ & $124.07 \pm 4.21$ & $113.24 \pm 8.77$ \\
\hline
\end{tabular}

Each value is expressed as mean \pm standard error.

Means having the same letter in the same row are significantly different.

\subsubsection{Triglycerides}

Table (11) represents the effect of polyzyme and/or lysoforte on triglceride level in serum of broiler chicks. At the 4th week of the experiment serum triglyceride level was significantly higher in polyzyme supplemented group than control and other supplemented groups. However, at 6 and 8 weeks the lysoforte supplemented group exhibited the highest level of triglyceride. It was significantly higher than all experimental groups.

Table 11. Effect of polyzyme and/or lysoforte on triglyceride level in serum of broiler chicks

\begin{tabular}{ccccc}
\hline \multirow{2}{*}{ Period (weeks) } & \multicolumn{4}{c}{ Triglycerides (mg/dl) } \\
\cline { 2 - 5 } & Control & Polyzyme & Lysoforte & Poly.+Lyso \\
\hline 4 & $106.4 \pm 10.19^{\mathrm{a} * * *}$ & $166.77 \pm 69.92^{\mathrm{abc}}$ & $139.9 \pm 6.37^{\mathrm{b}}$ & $76.49 \pm 14.17^{\mathrm{c}}$ \\
6 & $59.04 \pm 3.46^{\mathrm{ab}}$ & $84.62 \pm 5.75^{\mathrm{ac} * *}$ & $139.75 \pm 5.07^{\mathrm{bcd} \mathrm{d}^{* * *}}$ & $72.2 \pm 5.94^{\mathrm{d}}$ \\
8 & $51.58 \pm 1.85^{\mathrm{a} * * *}$ & $54.04 \pm 4.09^{\mathrm{b}}$ & $76.22 \pm 5.09^{\mathrm{abc}}$ & $52.67 \pm 3.94^{\mathrm{c}}$ \\
\hline
\end{tabular}

Each value is expressed as Mean \pm Standard Error.

$* * \mathrm{p}<0.01, * * * \mathrm{p}<0.001$ versus control.

\subsubsection{Glucose}

Table (12) represents the effect of polyzyme and/or lysoforte on glucose level in the serum of broiler chicks. At 4 weeks of the experiment there was no significant difference between all supplemented groups versus control group. However, at 6 weeks of the experiment there was a significant increase in glucose level in lysoforte supplemented group versus control and other supplemented groups. At 8 weeks of the experiment both polyzyme and lysoforte supplemented groups represent a significantly higher serum glucose levels than that of the control.

Table 12. Effect of polyzyme and/or lysoforte on glucose level in serum of broiler chicks

\begin{tabular}{ccccc}
\hline \multirow{2}{*}{ Period (weeks) } & \multicolumn{4}{c}{ Glucose (mg/dl) } \\
\cline { 2 - 5 } & Control & Polyzyme & Lysoforte & Poly.+Lyso. \\
\hline 4 & $208.88 \pm 10.54$ & $227.15 \pm 6.24$ & $220.8 \pm 6.43$ & $213.25 \pm 7.3$ \\
6 & $200.97 \pm 1.63^{\mathrm{a}^{* * *}}$ & $207.92 \pm 2.57^{\mathrm{b}}$ & $229.76 \pm 4.56^{\text {abc }}$ & $203.08 \pm 4.74^{\mathrm{c}}$ \\
8 & $174.05 \pm 5.95^{\text {ab }}$ & $209.83 \pm 8.91^{\mathrm{a}^{*}}$ & $216.76 \pm 4.57^{\mathrm{b}^{* *}}$ & $193.55 \pm 12.68$ \\
\hline
\end{tabular}

$* \mathrm{p}<0.05, * * \mathrm{p}<0.01, * * * \mathrm{p}<0.001$ versus control.

\subsection{Effect on Thyroid and Thyroid Stimulating Hormones}

Tables 13-15 represent the effect of polyzyme and lysoforte either alone or in combination on serum thyroid stimulating hormone (TSH), thyroxine (T4) and triiodothyronine (T3), respectively. No significant differences were observed in serum TSH and T4 levels between all supplemented groups and control during the whole sampling periods. Meanwhile, at 4 weeks of the experiment, the group supplemented with lysoforte exhibitred the highest level of T3, it was significantly higher than that of polyzyme supplemented group. At 6 weeks no significant changes were observed between control, polyzyme and lysoforte supplemented groups, while T3 
level in the group supplemented with mixed additives was significantly lower than that of the control group. However, at 8 weeks of the experiment, the control group exhibited the lowest level of serum T3. It was significantly lower than groups supplemented with polyzyme alone and in combination with lysoforte.

Table 13. Effect of polyzyme and/or lysoforte on thyroid stimulating hormone (TSH) in serum of broiler chicks

\begin{tabular}{ccccc}
\hline \multirow{2}{*}{ Period (weeks) } & \multicolumn{4}{c}{ TSH $(\mu \mathrm{g} / \mathrm{dl})$} \\
\cline { 2 - 5 } & Control & Polyzyme & Lysoforte & Poly.+ Lyso. \\
\hline 4 & $0.48 \pm 0.03$ & $0.45 \pm 0.02$ & $0.50 \pm 0.03$ & $0.43 \pm 0.02$ \\
6 & $0.44 \pm 0.03$ & $0.49 \pm 0.01$ & $0.49 \pm 0.03$ & $0.48 \pm 0.03$ \\
8 & $0.46 \pm 0.02$ & $0.42 \pm 0.03$ & $0.50 \pm 0.03$ & $0.49 \pm 0.03$ \\
\hline
\end{tabular}

Each value is expressed as Mean \pm Standard Error.

Table 14. Effect of polyzyme and/or lysoforte on thyroxine (T4) level in serum of broiler chicks

\begin{tabular}{ccccc}
\hline \multirow{2}{*}{ Period (weeks) } & \multicolumn{4}{c}{$\mathrm{T} 4(\mu \mathrm{g} / \mathrm{dl})$} \\
\cline { 2 - 5 } & Control & Polyzyme & Lysoforte & Poly.+ Lyso. \\
\hline 4 & $0.75 \pm 0.12$ & $0.61 \pm 0.09$ & $0.98 \pm 0.09^{\mathrm{a}}$ & $0.42 \pm 0.11^{\mathrm{a}}$ \\
6 & $0.79 \pm 0.16$ & $0.82 \pm 0.17$ & $0.65 \pm 0.18$ & $0.96 \pm 0.11$ \\
8 & $0.87 \pm 0.11$ & $0.96 \pm 0.15$ & $0.77 \pm 0.04$ & $0.95 \pm 0.09$ \\
\hline
\end{tabular}

Means having the same letter in the same row are significantly different.

Table 15. Effect of polyzyme and/or lysoforte on tri-iodothyronine (T3) level in serum of broiler chicks

\begin{tabular}{ccccc}
\hline \multirow{2}{*}{ Period (weeks) } & \multicolumn{4}{c}{$\mathrm{T} 3(\mu \mathrm{g} / \mathrm{dl})$} \\
\cline { 2 - 5 } & Control & Polyzyme & Lysoforte & Poly.+Lyso. \\
\hline 4 & $2.012 \pm 0.32$ & $1.67 \pm 0.22^{\mathrm{a}}$ & $2.93 \pm 0.26^{\mathrm{a}}$ & $2.04 \pm 0.24$ \\
6 & $2.90 \pm 0.25^{\mathrm{a}^{*}}$ & $2.28 \pm 0.24$ & $2.12 \pm 0.19$ & $1.73 \pm 0.17^{\mathrm{a}}$ \\
8 & $0.68 \pm 0.09^{\mathrm{ab}}$ & $1.29 \pm 0.18^{\mathrm{a}^{*}}$ & $0.89 \pm 0.05$ & $1.23 \pm 0.16^{\mathrm{b}^{*}}$ \\
\hline
\end{tabular}

$* \mathrm{p}<0.05$ versus control.

\subsection{Effect on the Length of Intestinal Villi and the Depth of Intestinal Crypts}

\subsubsection{Length of Intestinal Villi}

The result revealed that (Table 16) the length of duodenal villi in the polyzyme and lysoforte supplemented groups was significantly higher than that of the control group and group supplemented with mixed additives. On the contrary the length of the jejunal villi in the control group was significantly higher than that of all supplemented groups, while in the ileum the length of villi in the group supplemented with mixed additives was significantly higher than control and other experimental groups.

Table 16. Effect of polyzyme and/or lysoforte on length of villi in intestine of broiler chicks

\begin{tabular}{ccccc}
\hline \multirow{2}{*}{ Intestinal segment } & \multicolumn{4}{c}{ Length of villi } \\
\cline { 2 - 5 } & Control & Polyzyme & Lysoforte & Poly.+Lyso. \\
\hline Duodenum & $503.30 \pm 87.09^{\mathrm{ab}}$ & $819.60 \pm 98.49^{\mathrm{ac}^{* * * *}}$ & $716.67 \pm 23.84^{\mathrm{bd***}}$ & $557.83 \pm 41.93^{\mathrm{cd}}$ \\
Jejunum & $820.47 \pm 77.13^{\text {abc }}$ & $506.57 \pm 63.69^{\mathrm{a}^{*}}$ & $511 \pm 7.02^{\mathrm{b}^{*}}$ & $477.3 \pm 36.54^{* * *}$ \\
Ileum & $338.90 \pm 40.83^{\mathrm{a}^{\mathrm{a*}}}$ & $322.83 \pm 20.68^{\mathrm{b}}$ & $358.50 \pm 39.89^{\mathrm{c}}$ & $449.93 \pm 83.33^{\text {abc }}$ \\
\hline
\end{tabular}

Each value is expressed as Mean \pm Standard Error.

${ }^{*} \mathrm{p}<0.05,{ }^{* *} \mathrm{p}<0.01,{ }^{* * *} \mathrm{p}<0.001$ versus control. 


\subsubsection{Depth of Intestinal Crypts}

Table (17) clarifies the effect of feed supplementation with polyzyme and/or lysoforte on the depth of intestinal crypts in broiler chicks. The result revealed that, the depth of duodenal crypts in the group supplemented with lysoforte was significantly higher than that of the control and other supplemented groups. In the jejunum the depth of crypts in the polyzyme supplemented group was significantly higher than that of the control and other supplemented groups, while in the ileum the depth of crypts in group supplemented with polyzyme plus lysoforte was significantly higher than that of the control and other supplemented groups.

Table 17. Effect of polyzyme and/or lysoforte on depth of crypts in intestine of broiler chicks

\begin{tabular}{|c|c|c|c|c|}
\hline \multirow{2}{*}{ Intestinal segment } & \multicolumn{4}{|c|}{ Depth of Crypts } \\
\hline & Control & Polyzyme & Lysoforte & Poly.+Lyso. \\
\hline Duodenum & $105.05 \pm 7.62^{\mathrm{a}}$ & $100.50 \pm 5.48^{b}$ & $131.00 \pm 5.77^{\mathrm{abc} \pi}$ & $102.33 \pm 2.6^{\mathrm{c}}$ \\
\hline Jejunum & $101.33 \pm 0.33^{\mathrm{abc}}$ & $120.00 \pm 20.66^{\mathrm{ade}^{\text {a }}}$ & $86.00 \pm 3.84^{\mathrm{bd}^{*}}$ & $87.00 \pm 4.619^{c e^{\pi}}$ \\
\hline Ileum & $40.667 \pm 2.18^{\mathrm{a}^{x *}}$ & $53.00 \pm 7.311^{\mathrm{b}^{* \pi}}$ & $61.33 \pm 5.925^{\mathrm{c}^{\uparrow}}$ & $89.00 \pm 7^{\mathrm{abc}}$ \\
\hline
\end{tabular}

Each value is expressed as Mean \pm Standard Error.

\subsection{Histopathological Finding}

Figures 1-12 show the results of histopathological examination of the liver, spleen and bursa of Fabricious of all experimental groups.

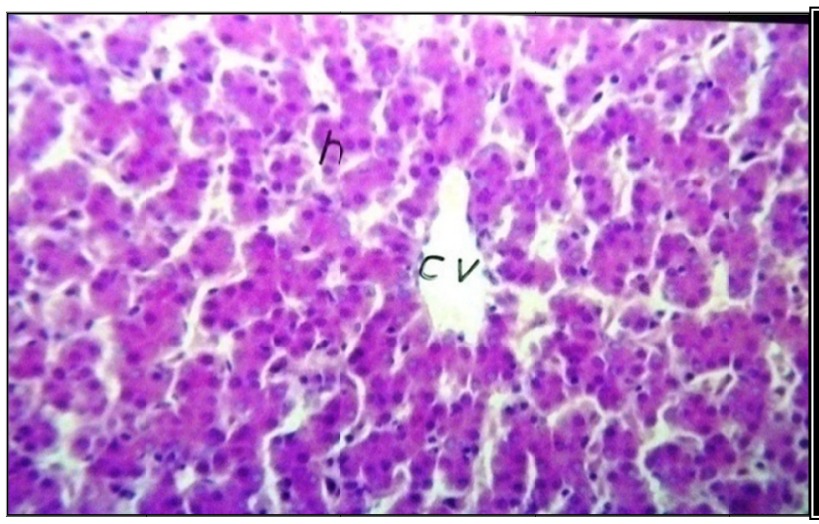

Figure 1. liver of control chicks at the end of the experiment (H\&Ex80). It reveals normal histological structure of the central vein $(\mathrm{C} . \mathrm{V})$ and surrounding hepatocytes $(\mathrm{h})$

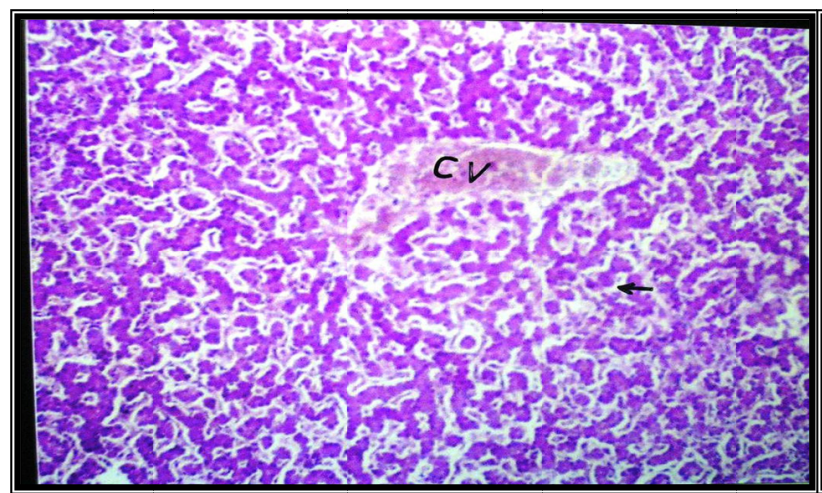

Figure 3. Liver of lysoforte supplemented group 8 weeks after supplementation (H\&Ex40). Showing congestion in the central vein (C.V) and sinusoids (arrow)

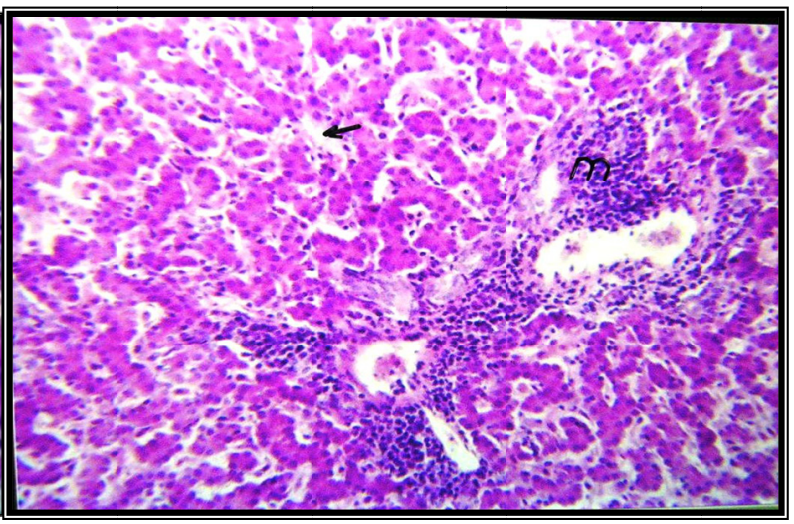

Figure 2. Liver of polyzyme supplemented group 8 weeks after supplementation (H\&Ex80). The portal area showed lymphoid cells infiltration in the portal area $(\mathrm{m})$ associated with congestion in the hepatic sinusoids (arrow)

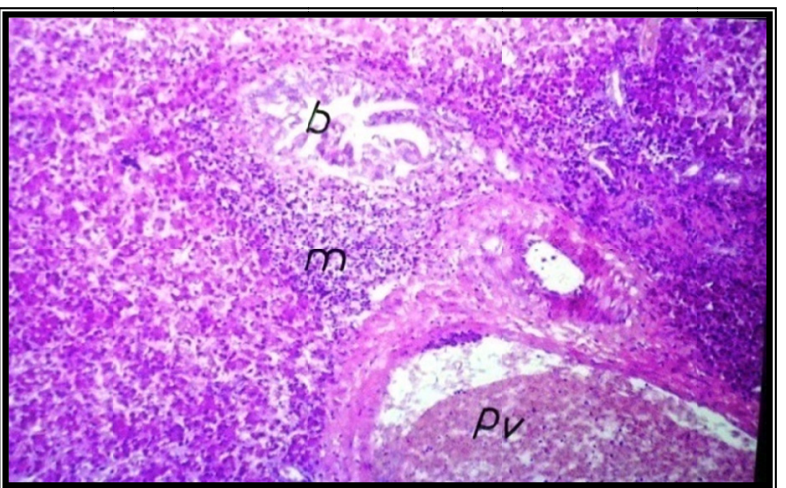

Figure 4. Liver of chicks supplemented with both additives for 8 weeks (H\&E X40). Showing congestion in the portal vein(PV), hyperplasia in bile duct (b)and lymphoid cell infiltration in portal area 


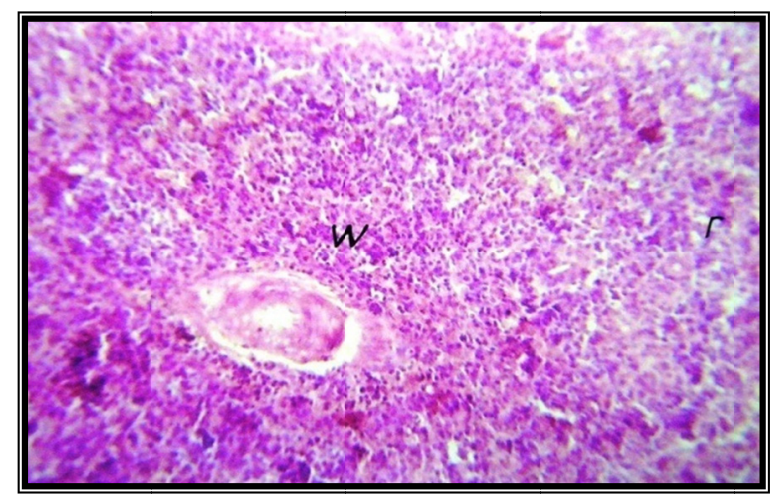

Figure 5. Spleen of control chicks at the end of the experiment (H\&Ex64).Showing normal histological structure of the follicular blood vessels (f) and surrounding lymphoid follicles of the white pulps

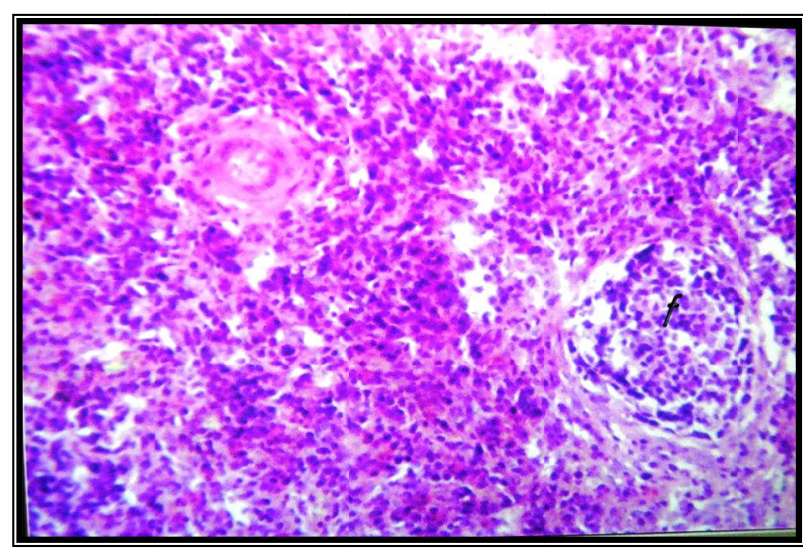

Figure 7. Spleen of lysoforte supplemented group 8 weeks after supplementation (H\&E x80). Showing lymphoid cells hyperplasia detected in the white pulps (f) as focal circumscribed round areas of lymphoid cells aggregation

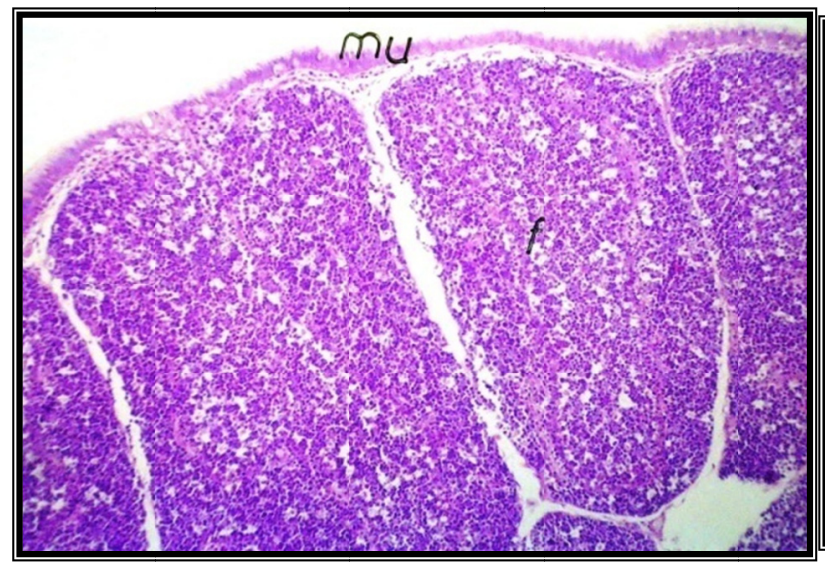

Figure 9. Bursa of Fabricious of control group at the end of the experiment (H\&Ex40). Showing normal histological structure of the mucosal lining $(\mathrm{mu})$ epithelium and the underlying lymphoid follicles (f)

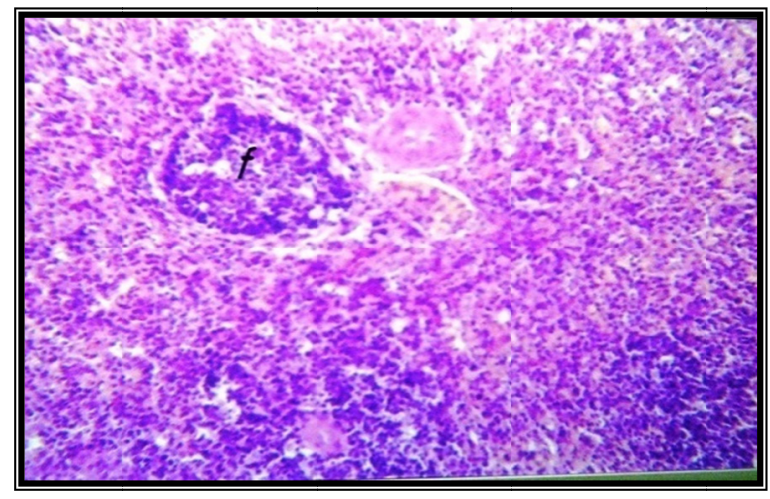

Figure 6. Spleen of polyzyme supplemented group 8 weeks after supplementation (H\&E x64). Showing lymphoid cells hyperplasia (f) in the white pulps as focal circumscribed round areas of lymphoid cells aggregation

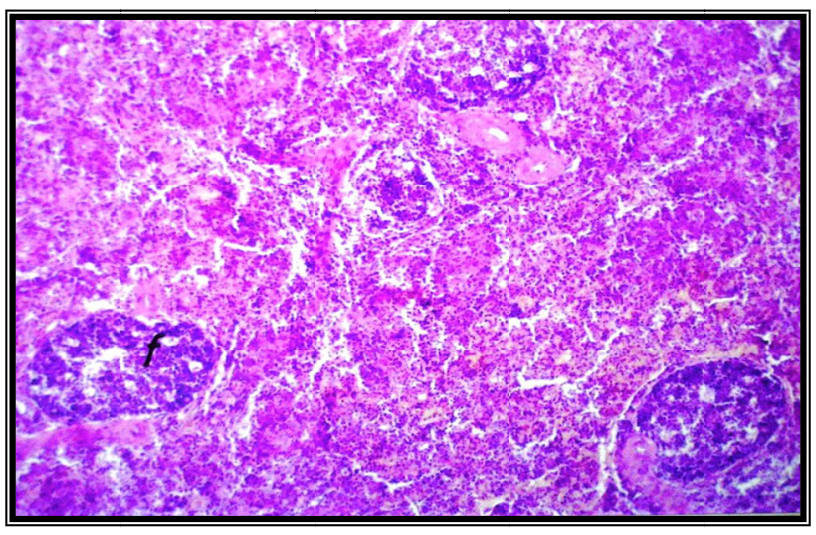

Figure 8. Spleen of polyzyme plus lysoforte supplemented group 8 weeks after administration (H\&Ex40). Showing Lymphoid cells hyperplasia as focal circumscribed round areas of lymphoid cell aggregation

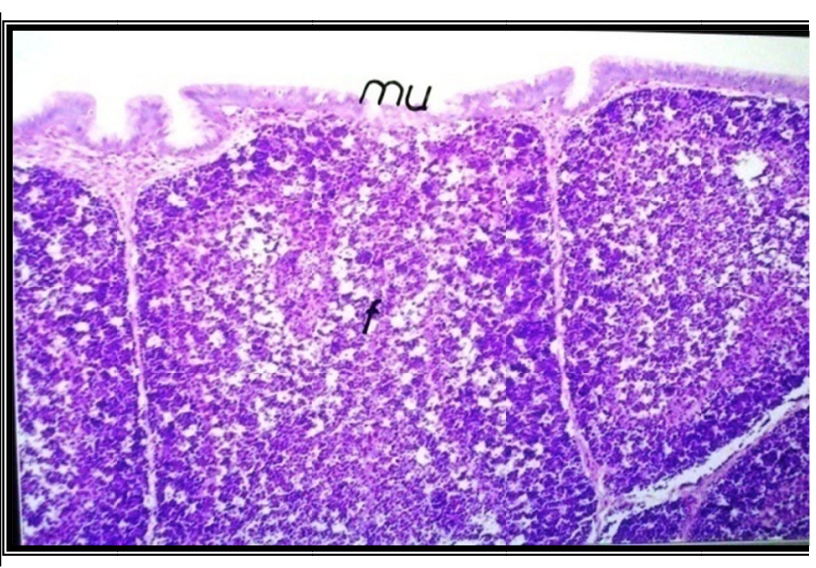

Figure 10. Bursa of Fabricious of polyzyme supplemented group after 8 weeks (H\&Ex40). Showing lymphoid cells hyperplasia in the lymphoid follicles (f) of the mucosal layer (mu) 


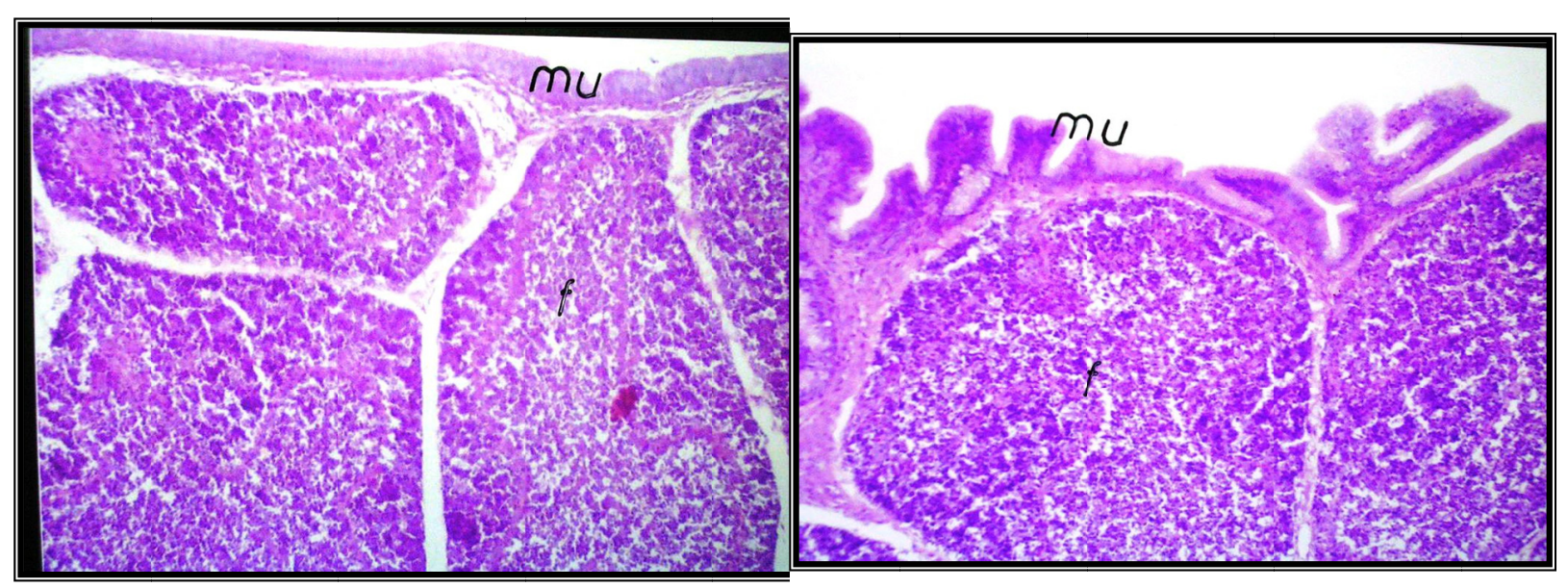

Figure 11. Bursa of lysoforte supplemented group 8 weeks after supplementation (H\&E, b40). Showing lymphoid cell hyperplasia in the lymphoid follicles (f)
Figure 12. Bursa of poly.+lyso. group after 8 weeks

(H\&E x40). Showing lymphoid cell hyperplasia in the underlying lymphoid follicles (f)

\section{Discussion}

The result of the present study revealed that both feed additives either alone or in combination produced a significant improvement in the body weight, body weight gain and feed conversion ratio of supplemented chicks versus control during most of the first 7 weeks of the experiment. However, no significant changes were recorded in all supplemented groups versus control during the $8^{\text {th }}$ week of the experiment. The growth promoting effect of polyzyme reported in the present study was in agreement with the study of Mousa (2008) who found that addition of multienzymes into broilers diet enhanced the energy utilization and improved body weight gain and feed conversion ratio. Moreover, Olukosi et al. (2007) reported that exogenous enzymes used in poultry diet usually resulted in improvement of growth performance, enhancement of flock uniformity and reduction in nutrient waste released to the environment.The mechanism by which enzymes induce improvement in performance is not yet exactly known. A number of researchers attributed the improvement induced by multienzymes in growth performance to the increase in ileal metabolizable energy (Yu et al., 2007). The earlier study of White et al. (1981) stated that supplementation of cereal diets with microbial enzyme was found to counteract the increase in digesta viscosity which is produced by antinutritional compounds identified in cereals and known as non-starch polysaccharides. The antinutritional effect of non-starch polysaccharide (NSPs) were attributed in part to changes in gut viscosity which slow the passage rate of ingested material, impared interaction between nutrients and digestive compounds, and restricted nutrients diffusion and transport by gelling of the chyme and interfering with the unstirred water layer (Annison \& Choct, 1991). Zhou et al. (2009) found that multienzymes supplementation enhanced metabolizable energy value of diet and improved average daily gain of broilers by preventing the formation of viscous digesta. The results of the current study are also in agreement with those obtained by Zang et al. (2011) who reported that administration of lysophosphatidylcholine improved feed conversion and weight gain in chickens. In the same respect Melegy et al. (2010) concluded that chicken fed ration supplemented with lysoforte showed a significant increase in final body weight, body weight gain and efficiency. The growth promoting effect of lysoforte may be attributed to its unique mode of action on enhancement of digestion and absorption of fat and other nutrient. In this concern, Khidir et al. (1995) found that lysoforte can enter into the gut membrane and increase the porosity of the membrane encouraging nutrients in the lumen of the gut to pass across the membrane into the blood. Moreover, Lioyd et al. (1999) during their study on lipid absorption reported that phosphatidylcholine may affect intestinal absorption of lipids by influencing the following intra luminal events: a) The rate of lipolysis, b) formation and diffusion of mixed micelles across the unstirred layer and c) transferring miceller lipids to the brush border membrane. Melegy et al. (2010) attributed the growth promoting effect of lysoforte to its ability to enhance the digestion of fat by facilitating its emulsification with better fat absorption. The growth promoting effect of lysoforte on broiler performance reported in the present study is not only due to enhancement of digestion and absorption of fats as previously mentioned, but it may also be due enhancement of digestion and absorption of other nutrients especially protein. This suggestion is supported by the earlier finding of O'doherty et al. (1973) who stated that phospholipids stimulate protein synthesis during fat absorption. Reynier et al. (1985) further added that lysoforte has a main role in increasing protein solubility, absorption and synthesis. In the same way Schwarzer and Adams (1996) 
stated that lysoforte was found to assist and promote the absorption of different nutrients and Xing et al. (2004) further added that lysoforte improves digestibility of fat and proteins. Moreover, the combination between polyzyme and lysoforte in the current study produced a significant increase in the average weekly body weight, body weight gain, feed conversion ratio and feed efficiency. However, this combination did not produce any additional benefits regarding all measured parameters. Consequently it is more economic to get the desired improvement in bird's performance by adding either polyzyme or lysoforte to broilers feed and there is no need to add both additives.

Supplementation of broilers ration in the current study with polyzyme or lysoforte either alone or in combination did not produce any significant changes in the activities of ALP, AST and ALT during the whole experimental periods. These results indicate that polyzyme and lysoforte are safe and did not alter hepatic function of broiler chicks. Ibrahim and Saleh (2005) reported that addition of multienzymes (protease, $\alpha$-amylase, lipase and $\beta$-glucanase) to broilers ration did not affect plasma ALT and AST concentration. In the same way Mousa (2008) couldn't detect any significant changes in the activity of serum AST of broiler chicks after adding multienzymes to their feeds. Abaza and Omara (2011) proved that enzymes preparation containing cellulose, $\beta$-glucans, $\alpha$-amylase, protease and lipase significantly improved liver function as it decreased AST significantly, while ALT values were not significantly affected. Concerning lysoforte Melegy et al. (2010) reported that serum GPT and GOT activities was not significantly affected by lysoforte fortification. However, no available literature concerning the effect of adding a combination of polyzyme and lysoforte to broilers diet on liver enzymes could be found. Moreover, polyzyme and lysoforte either alone or in combination did not produce any significant alteration in serum creatinine level during the whole sampling periods. These results indicate that all feed additives used are safe and did not alter renal function. The study of Mousa (2008) revealed that supplementation of broiler diet with kemzyme did not produce any significant alteration in serum creatinine level 4 weeks after supplementation, while, it significantly decreased its level at 6 and 8 weeks. No significant changes in the serum cholesterol level between control and all supplemented groups could be detected all over the experimental period. This result is in accordance with a number of studies who recorded that addition of multienzymes to broiler ration did not induce any significant changes in total cholesterol level in broilers (El-Menawey et al., 2010). Moreover, Melegy et al. (2010) demonstrated that cholesterol level was not significantly affected by soy phospholipid supplementation. The results of the present study also demonstrated that polyzyme induced a significant increase in serum triglyceride at 4 weeks of the experiment, while at 6 and 8 weeks both polyzyme and lysofort produced a significant increase in its level versus control. The lysoforte supplemented group exhibited the highest level of serum triglycerides. It was significantly higher than other supplemented groups. However, no significant changes in triglyceride level were observed in the group supplemented with both additives. The increase in triglycerides reported in the present study may be attributed to the improvement in fat digestion and absorption induced by adding either polyzyme or lysoforte to broilers feed. This result matched with those of Mousa (2008) who found that supplementation of broilers ration with kemzyme induced a significant increase in serum triglycerides level and Saleh et al. (2006) who found that kemzyme supplementation to turkeys increased significantly blood triglycerides level. Contrary to the obtained results Melegy et al. (2010) recorded that emulsifiers did not affect triglycerides level. On the other hand Cho et al. (2012) found that the level of serum triglycerides in emulsifier treatment was decreased significantly. Supplementation of broilers ration with polyzyme and lysoforte either alone or in combination in the present study did not induce any significant increase in blood glucose level versus control at 4 weeks of the experiment. However, at the $6^{\text {th }}$ week, lysoforte supplemented group exhibited a significant increase in blood glucose level versus control and other supplemented groups. At the end of the experiment polyzyme and lysoforte supplemented groups show a significant increase in blood glucose level as compared to control group. Multienzymes supplementation was reported to increase blood glucose level in growing turkeys (Saleh et al., 2006) and broilers ((Mousa, 2008). Gibson et al. (1980) stated that the increase in blood glucose level induced by multienzymes supplementation may be utilized for energy production, glycogen synthesis in the liver, fatty acids synthesis as well as synthesis of non essential amino acids and other metabolites. Moreover, concerning the effect of emulsifiers and absorption enhancers, Koochaksaraie et al. (2011) found that supplementation of emulsifiers to diet of chicks was accompanied by an increase in serum glucose levels as age of birds advanced. On the other hand Cho et al. (2012) could not detect any changes in blood glucose level in chicken fed multienzymes either alone or in combination with emulsifiers.

In the current study, no significant differences were observed in serumTSH and T4 during the whole sampling periods. Meanwhile, at the $4^{\text {th }}$ week of the experiment, the group supplemented with lysoforte exhibitred the highest level of T3, it was significantly higher than that of polyzyme supplemented group. At the $8^{\text {th }}$ week of the experiment, the control group exhibited the lowest level of serum T3. It was significantly lower than groups 
supplemented with polyzyme alone and in combination with lysoforte. The group supplemented with polyzyme plus lysoforte did not show any additive increase than that supplemented with polyzyme alone, which clarify that the increase in T3 level was induced by polyzyme rather than lysoforte. Collin et al. (2003) suggested that supplementation of exogenous enzymes could enhance the digestion of feed and absorption of nutrients which in turn might stimulate T3 concentration. Adams (2001) revealed that blood level of T3 was elevated in broilers diet supplemented with enzymes. A similar phenomenon was reported by Saleh et al. (2006) who found that T3 level was significantly increased in broiler chicks supplemented with Kemzyme in their feeds, while T4 level was not significantly affected. At the same time Mousa (2008) stated that kemzyme did not induce any significant changes in serum TSH and T4 levels during the first six weeks of age. However, at the end of the 8th week of age a significant increase in blood level of T3 was recorded. Similarly Hajati et al. (2009) revealed that multienzymes addition to broiler chicks increased the concentration of T3 level at 28-44 days and reduced the concentration of serum T4. The polyzyme-induced increase in serum T3 level reported in the current study might be attributed to its direct or indirect stimulatory effect on the deiodinase activity in liver and kidney tissue promoting the transformation of T4 to T3 as described by Mousa (2008).

The significant increase in villus length and crypt depth of chicks supplemented with Polyzyme and/or Lysoforte in the present study might improve nutrient digestibility and provide more surface area for nutrient absorption. Pluske et al. (1996) assumed that an increased villus height is paralleled by an increased digestive and absorptive function of the intestine due to increased absorptive surface area, expression of brush border enzymes and nutrient transport system. Moreover, Loodi et al. (2004) stated that the enlargement of length and width of the intestinal villi increases the absorptive surface that is prominent when feed additives were applied. Mathlouthi et al. (2002) concluded that exogenous enzymes improved nutrient digestibility by improving the absorption capacity of small intestine through increasing the villus surface and concentration of conjugated bile acid. In a more recent study, Neto et al. (2012) found that inclusion of enzymatic complex increased significantly the height of villi of duodenal mucosa. The authors added that, the greater height of the villi of broilers that received enzymes can be related to a regeneration process and consequently to a better absorption.

The congestion in hepatic veins and sinusoids detected from histopathological examination of the liver in the current study may be attributed to the improvement in the digestion and metabolism of lipids and proteins induced by adding polyzyme and lysoforte to broiler feed. Theil and Lauridsen (2007) reported that in avian species liver is the most important organ in the intermediary metabolism of lipids. Proteins are absorbed from the digestive tract in the form of amino acids which are taken up by the liver cells as portal vein blood flows through the liver sinusoids. In the liver, a portion of amino acids is utilized in protein synthesis (Sjaastad et al., 2003), since the liver has many different functions in the metabolism of proteins and fats, consequently it sounds logic to see hyperplasia and congestion in the hepatic vessels and sinusoids to meet the needs for the increase in the metabolism of proteins and fats induced by polyzyme and lysoforte in the present study. The histopathological study also revealed that supplementation of broilers ration with polyzyme and/or lysoforte produced lymphoid hyperplasis in the liver, spleen and bursa of Fabricious of all supplemented groups. This lymphoid hyperplasia might be due to the immune stimulant effect of the feed additives used. Immunostimulant effect of enzymes feed additives was previously reported by many investigators. Zoul et al. (2006) reported that Hemicell (beta mannanase-based enzyme) increased most of the relative immune organ weights, increased the concentration of serum IgM and T-lymphocytes proliferation of 6 weeks old broilers. Moreover, the addition of $360 \mathrm{mg} / \mathrm{kg}$ enzyme complex significantly increased livability of broilers (Yaun et al., 2008). The authors attributed this increase to the fact that enzyme complex accelerates the growth of immunity organs of the animal. Kettumen and Rautnen (2005) stated that the use of xylanase, amylase and protease enhanced nutrient uptake by intestinal cells and increased concentration of IgA in digesta which contributed to improvements in immune competence. Gao et al. (2007) reported that NSP-degrading enzymes supplementation to the wheat-based diet enhanced the immune system in broilers. Khaskar et al. (2012) found that inclusion of enzyme or growth promoters to the wheat based diet enhanced cell-mediated immune response and lowered stress in broilers chicks. Contrary to the previous findings Soltan (2009) stated that enzyme supplementation had no effect on spleen, bursa and thymus gland relative weight when compared with chick group on the same diet without supplementation. The reason for these contradictory results was explained by Sarmiento- Franco et al. (2003) who reported that the efficacy of exogenous enzymes depends on many factors such as the chemical characteristics of the ingredient and diet being evaluated, the microbial population in the gut, the age of the bird and the characteristics and amounts of the enzymes used.The effect of lysoforte and other emulcifiers on the immune status of broiler chicks needs further study, as no available literature could be found regarding this point. 


\section{Conclusion}

Supplementation of broilers ration with polyzyme and lysoforte either alone or incombination produced a significant improvement in birds performance during the first 6 weeks of age. Both feed additives are safe and did not affect liver and kidney functions. However, the combination between polyzyme and lysoforte increased the cost of broilers ration band did not add any further improvement to all measured parameters.

\section{References}

Abaza, I. M., \& Omara, M. E. (2011). Effect of dietary corn cobs and enzymes supplementation on growing rabbit's performance. J. Product. \& Dev., 16, 507-527.

Adams, C. A. (2001). Interaction of feed enzymes and antibiotic growth promotors on broiler performance. In J. Brufau (Ed.), Feed manufacturing in the Mediteranean region. Improving safety: From feed to food. Zaragoza: CIHEAM- IAMZ, 71-74.

Annison, C., \& Choct, M. (1991). Anti nutritive activities of cereal non-starch polysaccharides in broiler diets strategies minimizing their effect. World's poultry science journal, 47, 232-242. http://dx.doi.org/10.1079/WPS19910019

Armstrong, D. G. (1986). Gut-active growth promoters. In Control and Manipulation of Animal Growth (pp. 21-37). Animal Nutrition and Health R\&D, Roche Vitamins Ltd, Basel. Switzerland. Butterworths, London.

Banchroft, J., Stevens, A., \& Turner, D. (1996). Theory and practice of histological techniques (4th ed.). Churchil Livingstone, New York, London, San Francisco, Tokyo.

Burtis, C. A., Ashwood, E. R. (Eds.). (1999). Tiet z textbook of clinical chemistry (3rd ed.). Philadelphia, W.B. Saunders, 1799-1845.

Cho, H. J., Zhao, P. Y., \& Kim. I. H. (2012). Effect of emulcifier and multienzyme in different energy density diet on growth performance, blood profiles, and relative organ weight in broiler chicken. Journal of Agriculture Science, 4, 161-168.

Collin, A., Malheiros, R. D., Moraes, V. M. B., Veerle, P. V. A., Darras, M., Taouis, M., ... Buyse, J. (2003). Effects of dietary macronutrient content on energy metabolism and uncoupling protein mRNA expression in broiler chickens. Br. J. Nutr., 90, 261-269. http://dx.doi.org/10.1079/BJN2003910

Douglas, M. W., Parsons, C. M., \& Bedford, M. R. (2000). Effects of various soybean meal sources and Avizyme ${ }^{\circledR}$ on chick growth performance and ileal digestible energy. J. Appl. Poult. Res., 9, 74-80.

El-Menawey, M. A., Ali, A. H. R., Galal, M. A. A., \& Stino, F. K. R. (2010). Influence of enzyme supplementation in the diet on egg production, egg quality and some blood constituents of matrouh hens. Egypt. Poult. Sci., 30, 661-678.

Ewing, W. N., \& Cole, D. J. A. (1994). The Living Gut: An Introduction to Micro-Organisms in Nutrition. Context Graphics, Dungannon, UK.

Fossati, P., \& Prencipe, L. (1982). Serum triglycerides determined colon- metrically with an enzyme that produces hydrogen peroxide. Clin Chem, 28, 2077-2080.

Gao, F., Jiang, Y., Zhou, G. H., \& Han, Z. K. (2007). The effects of xylanase supplementation on growth, digestion, bbbbcirculating hormone and metabolite levels, immunity and gut micro flora in cockerels fed on wheat-based diets. Br. Poult. Sci., 48, 480-488. http://dx.doi.org/10.1080/00071660701477320

Gibson, W. R., Bourne, A. R., \& Serina, C. (1980). D-Xylose transport in isolated skeletal muscle of chickens: Effect of insulin and tolbutamide. Comparitive Biochemistry Physiology, 67, 41-47.

Hajati, H., Rezaei, M., \& Sayyahzadeh, H. (2009). The effects of enzyme supplementation on performance, carcass characteristics and some blood parameters of broilers fed on corn-soybean meal-wheat diets. Inter. J. Poult. Sci., 8, 1199-1205. http://dx.doi.org/10.3923/ijps.2009.1199.1205

Hertrampf, J. W. (2001). Lecithin improves poultry performance. Poult. Int., Nov., 26-30.

Houshmand, M., Azhar, K., Zulkifi, I., Bejo, M. H., Meimandipour, A., \& Kamyab, A. (2011). Effect of non-antibiotic feed additives on performance tibila dyschondroplasia incidence and tibia characteristics of broilers fed low calcium diets. Animal Physiology and Animal Nutrition, 95, 351-358. http://dx.doi.org/10.1111/j.1439-0396.2010.01061.x

Ibrahim, K. A., \& Saleh, E. S. (2005). Response of male broiler chicks to skip a day feeding Programs. Egypt. Poult. Sci., 25, 351-37. 
Kettumen, H., \& Rautnen, N. (2005). With betaine and exogenous enzymes towards improved intestinal health and immunity and better performance of broiler chicks. Poult.Sci., 84, 47.

Khaskar, V., Golin, B., \& Kermanshahi, H. (2012). Immune response and ileal microflora in broilers fed wheat-based diet with or without enzyme Endofeed W and supplementation of thyme essential oil or probiotic. Prima Lac, African Journal of Biotechnology, 11, 14716-14723.

Khidir, M. A., Stachecki, J. J., Krawetz, S. A., \& Arment, D. R. (1995). Rapid inhibition of mRna synthesis during preimplantation embryo development,vital pre meabilization by lysolecithin potentiate the action of a-amanitin. Exp. Cell Res, 219, 619-625. http://dx.doi.org/10.1006/excr.1995.1272

Koochaksaraie, R. R., Irani, M., \& Gharavysi, S. (2011). The effect of cinnamon powder feeding on some blood metabolites in broiler chicks. Rev. Bras. Cienc. Avic., 13, 197-201.

Lioyd, J., Todd, D. A., \& John, E. (1999). Serial phospholipid analysis in preterm infants: comparison of Exosurf and Survanta. Early human Dev., 54, 157-168. http://dx.doi.org/10.1016/S0378-3782(98)00086-3

Loodi, M. M., Moraes, V. B. M., Nakaghi, L. S. O., Tuca, F. M., Hannas, M. I., \& Ariki, J. (2004). Mannan oligosaccharide, organic acids on performance and intestinal morphometric characteristic of broiler chicken. Abstract of Alltechs $20^{\text {th }}$ Annual Symposium, Nicholas ville, Kentuchy, U.S.A.

Mathlouthi, N., Saulnier, L., Quemener, B., \& Larbier, M. (2002). Xylanase, $\beta$-glucanase, and other side enzymatic activities have greater effects on theviscosity of several feedstuffs than xylanase and $\beta$-glucanase used aloneor in combination. J. Agric. Food Chem., 50, 5121-5127. http://dx.doi.org/10.1021/jf011507b

Meiattini, F., Prencipe, L., Bardelli, F., Giannini, G., \& Tarli, P. (1978). The 4-hydroxybenzoate/4-aminophenazone chromogenic system used in the enzymic determination of serum cholesterol. Clin. Chem., 24, 2161-2165.

Melegy, T., Khaled, N. F., El-Bana, R., \& Abdellatef, H. (2010). Dietary fortification of a natural biosurfactant, Lysolecithin in broiler. African journal of agricultural research, 5, 2886-2892.

Mousa, A. S. (2008). Physiological studies on the effects of some feed additives on some metabolic and haemostatic parameters in broilers. $\mathrm{PhD}$ thesis. Cairo university.

Murray, R., Kaplan, A., Rubaltelli, F. F., \& Hammerman, C. (1984). Aminotransferases. Clin. Chem., 1112-119. The C.V. Mosby Co. St Louis. Toronto. Princeton, a.

Nakano, T., Inoue, I., Alpers, D. H., Akiba, Y., Katayama, S., Shinozaki, R., ... Komoda, T. (2009). Lysophosphatidylcholine for efficient intestinal lipid absorption and lipoprotein secretion in caco-2 cells. $J$. Clin. Biochem. Nutri., 45, 227-234. http://dx.doi.org/10.3164/jcbn.09-25

Neto, R. M., Ceccanlin, M. L., \& Fermandes, J. I. (2012). Productive performance, intestinal morphology and carcass yield of broilers fed conventional and alternative diets containing commercial enzymatic complex. International Journal of Poultry Science, 11, 505-516.

O’Doherty, P. J., Kakies, G., \& Kuksis, A. (1973). Role of luminal lecithin in intestinal fat absorption. Lipids, 8, 249-255. http://dx.doi.org/10.1007/BF02531899

Olukosi, O. A., Cowieson, A. J., \& Adeola, O. (2007). Age-related influence of a cocktail of xylanase, amylase and protease or phytase individually or in combination in broilers. Poultry Science, 86, 77-86.

Peric, L., Žikic, D., \& Lukic, M. (2009). Application of alternative growth promoters in broiler production. Biotechnology in animal husbandry, 25, 387-397. http://dx.doi.org/10.2298/BAH0906387P

Petterson, D., \& Aman, P. (1989): Enzyme supplementation of a poultry diet containing rye and wheat. Brit. J. Nutr., 62, 139-149. http://dx.doi.org/10.1079/BJN19890014

Pluske, J. R., Sba, P. M., Pethick, D. W., Durmic, Z., Mullan, B. P., \& Hampson, D. J. (1996). The incidence of swine dysentery in pigs can be reduced by feeding diets that limit the amount of fermentable substrate entering large intestine. J. Nutri., 26, 2920-2933.

Reynier, M. O., Lafont, H., Crotte, C., Sauve, P., \& Gerolami, A. (1985). Intestinal cholesterol uptake: comparison between mixed micelles containing lecithin \& lysolecithin. Lipids, 20, 145-150. http://dx.doi.org/10.1007/BF02534246

Saleh, F. M., Yamamoto, M. Tahrir, A., Ohtsuka, A., \& Hayashi, A. (2006). A new natural feed additive for broiler chicken. Poult. Sci. Asso. Annual Meetings. Edomonton, Canada, 36-54. 
Sarmiento- Franco, L., McNab, J. M., Pearson, A., \& Belmar-Casso, R. (2003). The effect of chaya leaf meal and exogenous enzymes on amino acid digestability in broilers. Br. Poult. Sci., 44, 458-463. http://dx.doi.org/10.1080/00071660310001598256

Schwarzer, K., \& Adams, C. (1996). The influence of specific phospholipids as absorption enhancer in animal nutrition. Fett-Lipid, 98, 304-308. http://dx.doi.org/10.1002/lipi.19960980905

Sjaastad, Q. V., Hove, K., \& Sand, O. (2003). Physiology of domestic animals (1 edn). International Book Distributing Co. (Publishing division).

Snedecor, G. W., \& Cochran, W. G. (1980). Statistical Methods (7th ed). Ames: Iowa State University Press.

Soares, M., \& Lopez-Bote, C. J. (2002). Effects of dietary lecithin and fat unsaturation on nutrient utilization in weaned piglets. Anim. Feed Sci. Technol., 95, 169-177. http://dx.doi.org/10.1016/S0377-8401(01)00324-8

Soltan, M. A. (2009). Growth performance, immune response and carcass traits of broiler chicks fed on graded levels of palm kernel cake without or with enzyme supplementation. Livestock research for Rural development, 21. Retrieved from http://www.lrrd.org/lrrd21/3/solt21037.htm

Taylor-Pickard, J. A., \& Spring, P. (2008). Gut efficiency; the key ingredient in pig and poultry production. Wageningen Academic Publishers. http://dx.doi.org/10.3920/978-90-8686-636-6

Thakur, C., Saikia, T. C., Yadav, R. N. (1997). Total serum levels of triiodothyronine (T3) thyroxine (T4) and thyrotropine (TSH) in school going children of Dibrugarh district: an endemic goitre region of Assam. Indian J Physiol Pharmacol, 41, 167-70.

Theil, P. K., \& Lauridsen, C. (2007). Interaction between dietary fatty acid and hepatic gene expression in livers of pigs during the weaning period. Livest. Sci., 108, 26-29. http://dx.doi.org/10.1016/j.livsci.2007.01.015

Toghyani, M., Tohidi, M., Gheisari, A. A., \& Tabei-dian, S. A. (2010). Performance, immunity, serum biochemical and hematological parameters in broiler chicks fed dietary thyme as alternative for an antibiotic growth promoter. Afr. J. Biotechnol., 9, 6819-6825.

Wenger, C., Kaplan, A., Rubaltelli, F. F., \& Hammerman, C. (1984). Alkaline phosphatase. Clin. Chem., 1094-1098. The C.V. Mosby Co. St Louis. Toronto. Princeton.

White, W. B., Bird, H. R., Sunde, M. L., \& Prentice, W. C. (1981). Effect of enzyme supplementation of a diet based on barley, and autoclave treatment, on apparent digestibility, growth performance and gut morphology of broilers. Anim. Feed Sci. Tec., 48, 237-251.

Xing, J. J., Ven Heugten, E., Li, D. F., Touchette, K. J., Coalson, J. A., Odgaard, R. L., \& Ordle, J. (2004). Effects of emulsification, fat encapsulation-solution and pelleting on weanling pigs performance. J. Anim. Sci., 82, 2601-2609.

Yaun, J., Yao, J., Yang, F., Yang, X., Wan, X., Han, J., ... Feng, X. (2008). Effects of supplementing different levels of a commercial enzyme complex on performance, nutrient availability, enzyme activity and gut morphology of broilers. Asian-Aust. J. Anim. Sci., 21, 692-700.

Yu, B., Wu, S. T., Liu, C. C., Gathier, R., \& Chiou, P. W. S. (2007). Effect of enzyme inclusion in a maize-soybean diet on broiler performance. Anim. Feed Sci. Tech., 134, $283-294$. http://dx.doi.org/10.1016/j.anifeedsci.2006.09.017

Zang, B., Haitao, L., Zhao, D., Guo, Y., \& Barri, A. (2011). Effect of fat type and lysophosphatidylcholine addition to broiler diets on performance, apparent digestibility of fatty acids, and apparent metabolizable energy content. Animal Feed Science and Technology, 163, 177-184. http://dx.doi.org/10.1016/j.anifeedsci.2010.10.004

Zhou, Y., Jiang, Z., Ly, D., \& Wang, T. (2009). Improved energy-utilizing efficiency by enzyme preparation supplemented in broiler diets with different metabolizable energy levels. Poult. Sci., 88, $316-322$. http://dx.doi.org/10.3382/ps.2008-00231

Zoul, X. T., Qiao, X. J., \& Xu, Z. R. (2006). Effect of $\beta$-mannanase (Hemicell) on hrowth performance and immunity of broilers. Poult. Sci., 85, 2176-9.

\section{Copyrights}

Copyright for this article is retained by the author(s), with first publication rights granted to the journal. 
This is an open-access article distributed under the terms and conditions of the Creative Commons Attribution license (http://creativecommons.org/licenses/by/3.0/). 